\title{
States Address Air Pollution from Energy through Energy Efficiency and Renewable Energy Programs
}

Throughout the nation - and the world - meeting energy needs without compromising environmental quality is an ongoing challenge. Facing that challenge, government officials, private companies, and individuals increasingly see renewable energy (RE) and energy efficiency (EE) technologies as ways to meet regulatory requirements for controlling air pollution, or to take voluntary steps to improve air quality.

$\mathrm{RE}$ and $\mathrm{EE}$ technologies are gaining attention in the air quality community as methods for preventing much of the air pollution from energy use. This fact sheet series highlights how RE and EE technologies can and are being used to reduce air emissions and meet environmental goals, showcasing case studies and technology-specific topics.

\section{RE and EE Can Help States Meet Regulatory Requirements}

The Department of Energy's (DOE) Office of Energy Efficiency and Renewable Energy (EERE) is partnering with others to promote a greater variety of deployment options for $\mathrm{RE}$ and EE technologies, and to assist with integration of those strategies. DOE air quality activities include pilot projects, analytic assistance, training, and outreach.

$\mathrm{RE}$ and $\mathrm{EE}$ technologies provide innovative ways to meet regulatory requirements through

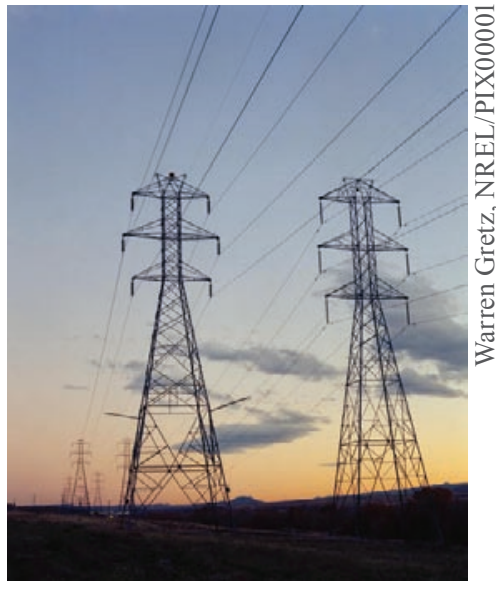

Energy efficiency and renewable energy technologies can help reduce electric-sector emissions. cap-and-trade programs and state implementation plans (SIPs). Three key issues are achieving sufficient scale (possibly through aggregation), undertaking regulatory innovation, and validating results to meet regulatory standards.

\section{Scale and Aggregation}

Most individual RE and EE projects are small and must be aggregated so that their cumulative air emissions effect can be considered in air regulatory processes in an effective manner. State sustainable energy plans and other state or regional RE or EE initiatives can help achieve larger numbers of projects, and air quality rules can be written to allow project aggregation.

\section{Regulatory Innovation}

States are working in partnership with federal agencies to undertake innovative regulatory approaches to apply RE and EE technologies to meet environmental objectives. DOE and the Environmental Protection Agency (EPA) are both supporting innovative programs in states to integrate energy and environmental goals. EPA has made vital innovations in regulations that allow RE and EE to be used in cap-and-trade programs and SIPs.

Cap and Trade. RE and EE provide nonemitting sources of energy, and may benefit competitively in a cap-and-trade program or from other regulations that increase the cost of emissions, without any RE/EE-targeted measures. In addition, these programs can be designed to provide a direct incentive to use RE and EE technologies.

When RE and EE are used where emissions caps are in effect, they will not directly reduce total emissions unless special steps are taken, because total emissions of capped pollutants tend to approach the cap. However, if they are used instead of an emitting technology, they will reduce the cost of emissions allowances. Cap-and-trade issues related to RE and EE are discussed in Incorporating Wind Generation in Cap-and-Trade Programs, accessible at www.nrel.gov/docs/fy06osti/40006.pdf.

State Implementation Plans. State and local governments choose from a wide range of air pollution control measures for SIPs. Some are interested in RE and EE where other emissions reduction opportunities are largely exhausted. Their goal: lowering nitrogen oxides (NOx) emissions to reduce ozone, fine particulate matter, and regional haze. Examples where states have recently included or have explored including electric-sector RE and EE in part of a SIP include Maryland, Texas, Louisiana, New Jersey, and the metropolitan Washington, D.C., region; this, in addition to the long-term use of alternative-fueled vehicles in SIPs. 


\section{Validation}

A key issue for RE and EE use in regulatory contexts is validating their application. Emissions reductions claimed in SIPs generally must meet the criteria that they are surplus, quantifiable, permanent, and enforceable. Regulatory innovations have allowed states to include some measures that would not otherwise meet all of these standards.

However, meeting these criteria would allow greater use of the technologies in SIPs as well as in some cap-and-trade programs. Thus, RE and EE project or program evaluation, including quantitative estimates of effects, is essential to regulatory applications. This fact sheet series includes examples of both streamlined quantification methods (New Jersey) and more detailed ones (Illinois) — see www.nrel.gov/docs/fy08osti/41173.pdf and www.nrel.gov/docs/fy08osti/42165.pdf.

\section{EPA SIPs Resources}

- Incorporating Emerging and Voluntary Measures into SIPS www.epa.gov/ttn/oarpg/t1/memoranda/evm_ievm_g.pdf

- Air Pollution and SIPS www.epa.gov/ebtpages/airairpostateimplementationplans.html

- State and Local Clean Energy Programs www.epa.gov/cleanenergy/stateandlocal/guidance.htm

- Air Quality Policy and Guidance Memos www.epa.gov/ttn/oarpg/t1pgm.html

- SIP Credit Guidance www.epa.gov/ttn/oarpg/t1/memoranda/ereseerem_gd.pdf

- Bundled Measures Policy and SIPS www.epa.gov/ttn/oarpg/t1/memoranda/10885guideibminsip.pdf

\section{Voluntary Use of RE and EE Improve Environmental Quality}

Many individuals and corporations reduce their environmental impact below levels required by regulation through voluntary efforts, including improving EE; installing RE; or purchasing green power, renewable energy certificates, or energy efficiency certificates. Voluntary use also occurs within supplemental environmental projects (SEPs). In this case, a company that has violated environmental regulations can negotiate to pay for a SEP involving RE or EE technologies instead of only paying a fine into a federal or state fund, thus targeting funds for a positive outcome for the company and the community.

\section{State Applications - What's Being Done}

In this fact sheet series, we highlight examples of DOE-EERE-funded pilot projects that partnered with states to use RE and EE to improve air quality in their regions. This series highlights just a few of the states: Illinois, New Jersey, and Texas.

- The Illinois project illustrates how detailed electric-sector modeling can quantify benefits from statewide RE and EE portfolio standards (www.nrel.gov/docs/fy08osti/42165.pdf).

- The New Jersey project refines a method for calculating summer NOx emissions reductions that could be used in other states (www.nrel.gov/docs/fy08osti/41173.pdf).

- The Texas project illustrates innovative quantification of the statewide legislation to promote large-scale RE and EE use (www.nrel.gov/docs/fy08osti/42164.pdf).

\section{Conclusions}

- States are facing challenges meeting air quality goals, before even considering additional growth in energy needs.

- Good quantification can show how RE and EE can reduce many air pollutants and greenhouse gases.

- Using RE and EE technologies to address air quality issues provides another option at a time when many other measures are exhausted and standards may become more stringent and expand to include greenhouse gases.

- RE and EE have been used in a regulatory context to meet SIP and cap-andtrade requirements, and may also be appropriate in regulations using offsets and standards.

- Consumer and corporate programs use RE and EE in a voluntary context, as do enforcement settlements.

For more information on individual state activities, please visit the Air Quality section of the DOE-EERE Weatherization and Intergovernmental Program (WIP) Web site at $h$ ttp://www.eere.energy.gov/wip/or NREL's Applying Technologies Web site at http://www.nrel.gov/applying_technologies/

\author{
Additional Information \\ Program Assistance \\ Pam Mendelson \\ Navarro Inc. for DOE Golden Field Office \\ pam.mendelson@go.doe.gov \\ 303-2754819 \\ Technical Assistance \\ Laura Vimmerstedt \\ National Renewable Energy Laboratory (NREL) \\ laura_vimmerstedt@nrel.gov \\ 303-384-7346
}

DOE/G0-102007-2506, December 2007

\section{A Strong Energy Portfolio for a Strong America}

Energy efficiency and clean, renewable energy will mean a stronger economy, a cleaner

environment, and greater energy independence for America. Working with a wide array of state, community, industry, and university partners, the U.S. Department of Energy's Office of Energy Efficiency and Renewable Energy invests in a diverse portfolio of energy technologies. Energy by the National Renewable Energy Laboratory, a DOE national laboratory. Printed with a renewable-source ink on paper containing at least $50 \%$ wastepaper, including $20 \%$ postconsumer waste.
For more information contact: EERE Information Center

1-877-EERE-INF

(1-877-337-3463)

www.eere.energy.gov 